\title{
Upper Pennsylvanian sediment dispersal and paleochannel orientation in the western part of the Sydney Coalfield, Cape Breton, Nova Scotia
}

\author{
P. McL. D. Duff \\ University of Strathelyde, GLasgow, Scotland \\ S. Forgeron \\ Cape Breton Development Corporation, Sydney, Nova Scotia \\ H.W van de Polz \\ University of New Brunswick, Fredericton, New Brunswick
}

\section{INTRODUCTION}

Orientation data from primary sedimentary structures in Carboniferous strata of the Sydney Basin, Nova Scotia, have been integrated with data from paleochannels mapped in underground coal mines. A predominant northeasterly transport direction is indicated by both sets of observations, contrary to earlier interpretations.

The Sydney Basin is situated in northeastern Cape Breton Island, Nova Scotia (Fig. 1), and extends a long way offshore. The Carboniferous strata of the basin include some $600 \mathrm{~m}$ thickness of productive coal measures within the Morien Group, which ranges in age from Westphalian C to Stephanian (Hacquebard 1972, Zodrow and Gastaldo 1982). The coal measures consist of alternations of coarse and fine sandstones and grey shales with seatearths and coals. Certain intervals are characterized by red and green mudstones while bituminous shales, commonly accompanied by thin limestone beds, are noticeable within the roof shales of some of the coal seams. Sandstone and small-pebble conglomerate infill paleochannels in the sequence. Although the fauna of the bituminous shales and limestones is regarded as non-marine, Hacquebard and Donaldson (1969) considered the coals (and the sequences in genera1) to be more typical of a paralic rather than a limnic type of coal basin.

MARITIME SEDIMENTS AND ATLANTIC GEOLOGY $18,83-90(1982)$
Offshore, the configuration of the basin is interpreted from seismic data, which indicates an easterly trending structure beneath the waters of the Cabot Strait, extending for an unknown distance into the Atlantic Ocean (King and MacLean 1976).

Despite the long history of coal mining in the Sydney area and the current interest in the offshore extension of the coalfield, little regional sedimentological work has been carried out that has used paleoenvironmental indicators and sediment dispersal patterns to aid undersea mining. Such knowledge would be of direct relevance to modern exploitation and, in particular, would be of help in the prediction of unstable roof and floor conditions and the estimation of mineable coal reserves (Forgeron 1980).

Hayes and Bell (1923) first recognized the economic importance of a sound knowledge of the physical factors controlling the deposition of the coalbearing rocks in the Sydney Basin. They inferred active transportation of sediments into the basin from the northwest, on the basis of a thick sandstone unit occurring in the vicinity of Sydney which, elsewhere, grades into rhythmic alternations of coarser and finer clastic strata containing numerous coal horizons (Hayes and Bell 1923, p. 5556.)

In subsequent studies, Bell (1938) reiterated his conclusion that the 


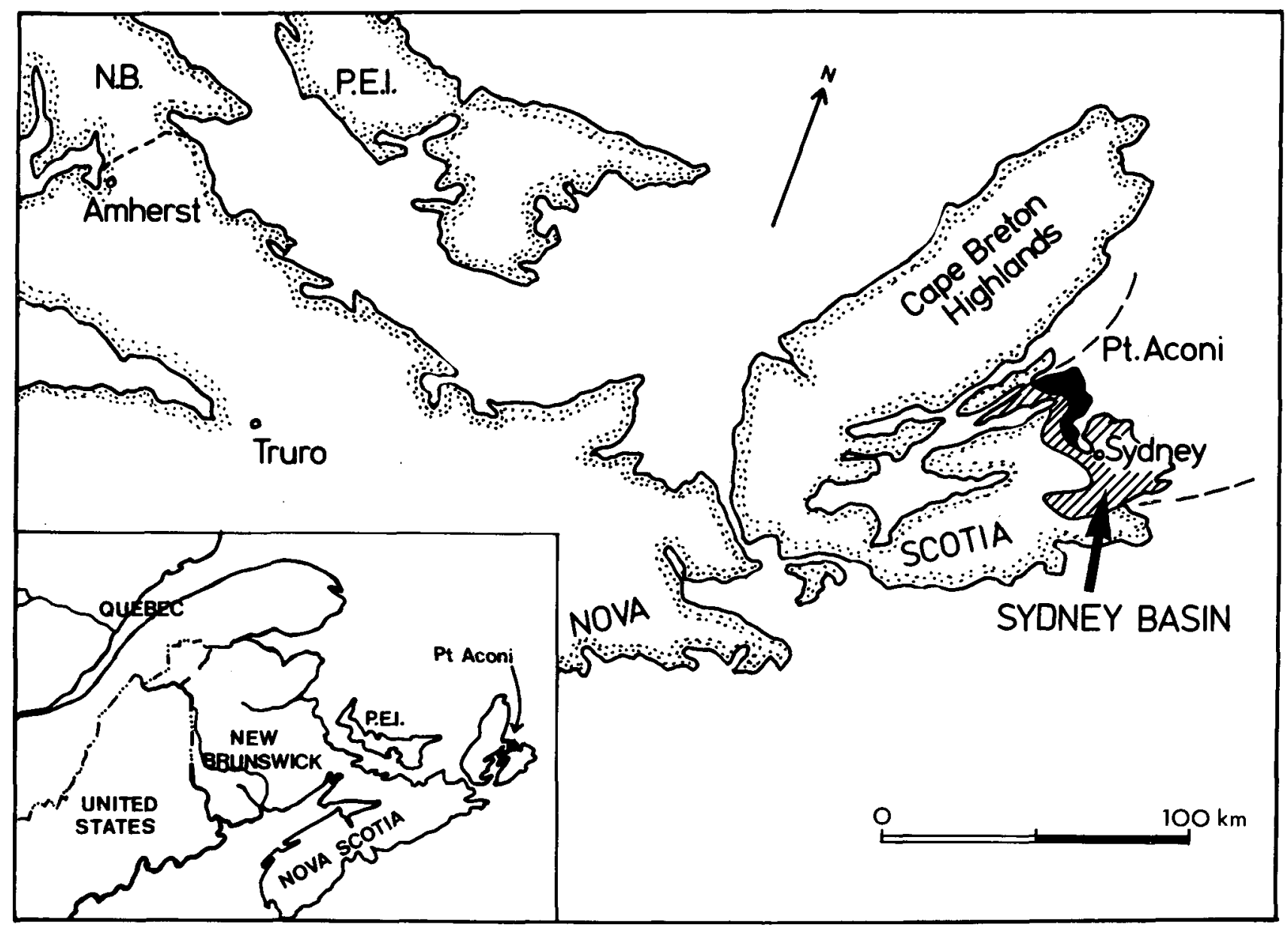

Fig. 1 - Location map showing the Sydney Basin and the Point Aconi study area of the Sydney Coalfield.

westerly or northwesterly source of the basin-fill, which he inferred to have come from the Cape Breton Highlands, was situated immediately to the northwest of the coalfield. A similar provenance was assumed by Gray and Gray (1941), who suggested that sedimentation was in the main from the northwest, induced by erosion of the "northern upland". Haites (1951, 1952), using underground information, studied the orientation of paleoriver channels ("washouts") cutting down into the "Mullins", "Phalen" and "Harbour Rider" seams. He pointed out that:

"the continental deposits comprising the Morien Group were laid down on a flood-plain environment ..... The river which built up this floodplain could be traced by its effects in the coal seams. Parts of this channel have been reconstructed in- dicating that its course was winding ..... Although the general trend of this river may have been more or less parallel to the present coastline*, its direction of flow has not yet been determined ...." (Haites 1951, p. 338).

\section{CHANNELS AND PALEOCURRENTS}

Recent detailed underground work by Forgeron (1980) on the orientation of channel sandstones encountered in the roof of worked coals and by diamond drilling, did not support the northwestto-southeast or west-to-east directions of sediment transport visualized by most

* This statement is ambiguous, but it seems apparent from the text that a northeast-southwest trend was meant Authors 


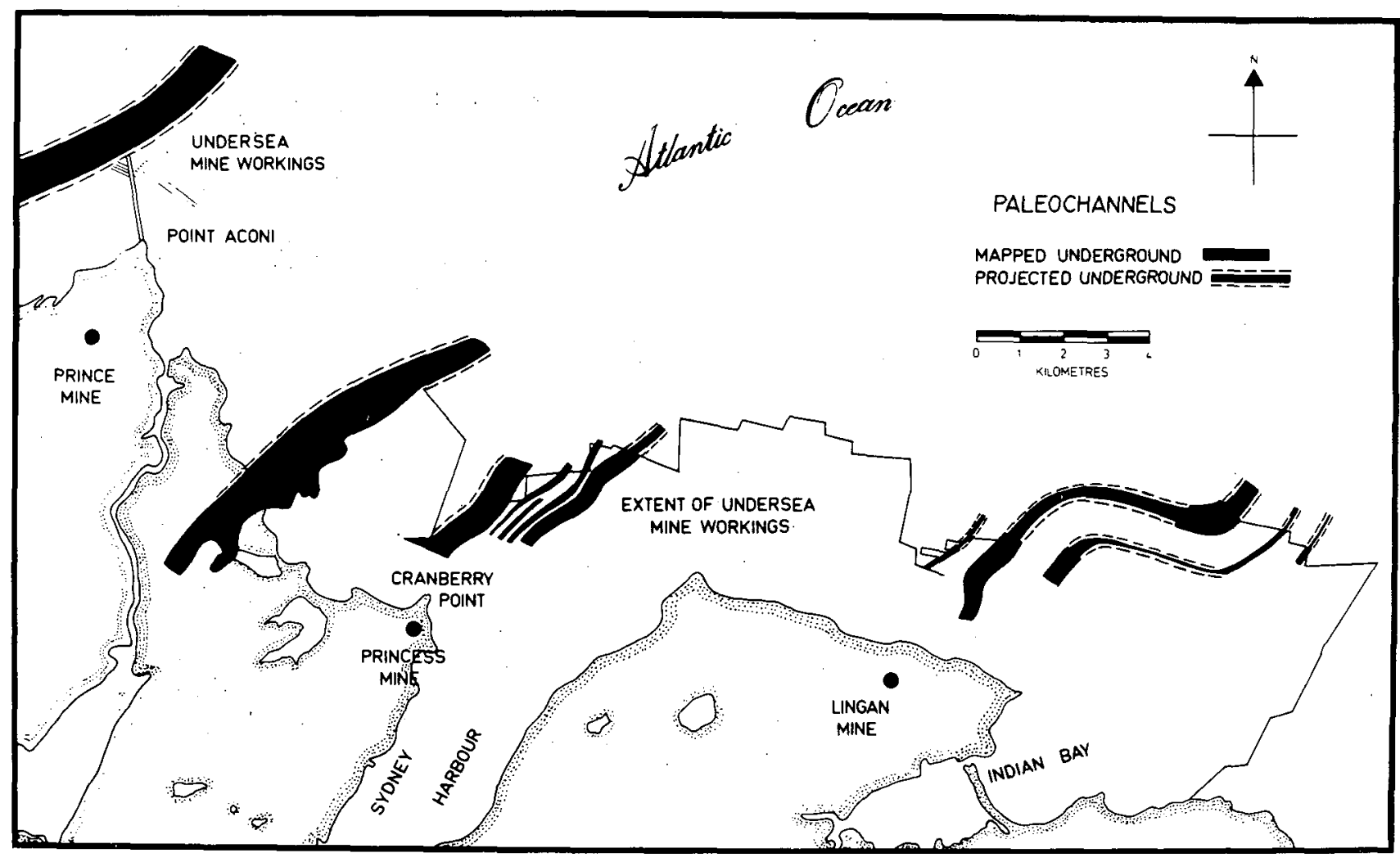

Fig. 2 - Subsurface distribution and orientation of fluvial channels, as exposed in the mine workings of the western part of the Sydney Coalfield.

earlier workers. He drew attention to the prevailing northeast-southwest trend of the channels mapped underground (Fig. 2), and confirmed that the channels had a tendency to occur more frequently in the synclinal areas of the coalfield than in the anticlinal areas (as indicated by Haites 1951). He concluded that the paleochannels probably originated from rivers draining the granitic source areas to the west and south of the basin.

Detailed knowledge of the orientation and frequency of occurrence of these paleochannels is important because of the hazards they pose in mining, even when separated from a coal seam by as much as $1.5 \mathrm{~m}$ of roof strata.

Although the underground workings help paleochannel mapping, it was not found possible to determine sediment transport directions within them as mining operations tend to avoid the channel sandstones. Hence the interpretation that the paleocurrents flowed to the northeast when coal measures were being deposited in the Sydney Basin could not be confirmed until surface observations on the azimuths of current structures were available.

While two of us (P.D. and V.d.P.) have as yet no information on that part of the coalfield lying east of Sydney Harbour, we have been studying the sedimentology of the western portion of the field for some time and, in particular, the shore section from Black Rock Point to Point Aconi, and from Point Aconi to Stubbert Point (Fig. 5). In this part of the coalfield, an outstanding feature of the strata is the extent of post-depositional soft-sediment deformation (Figs. 3 and 4 ). The effects of this deformation on primary sedimentary structures have been considerable and greatly reduce the number of reliable observations of sediment transport directions that can be made. Fortunately, however, not all sediments seem to have been affected to the same extent; in some of the sandstones, current direc- 


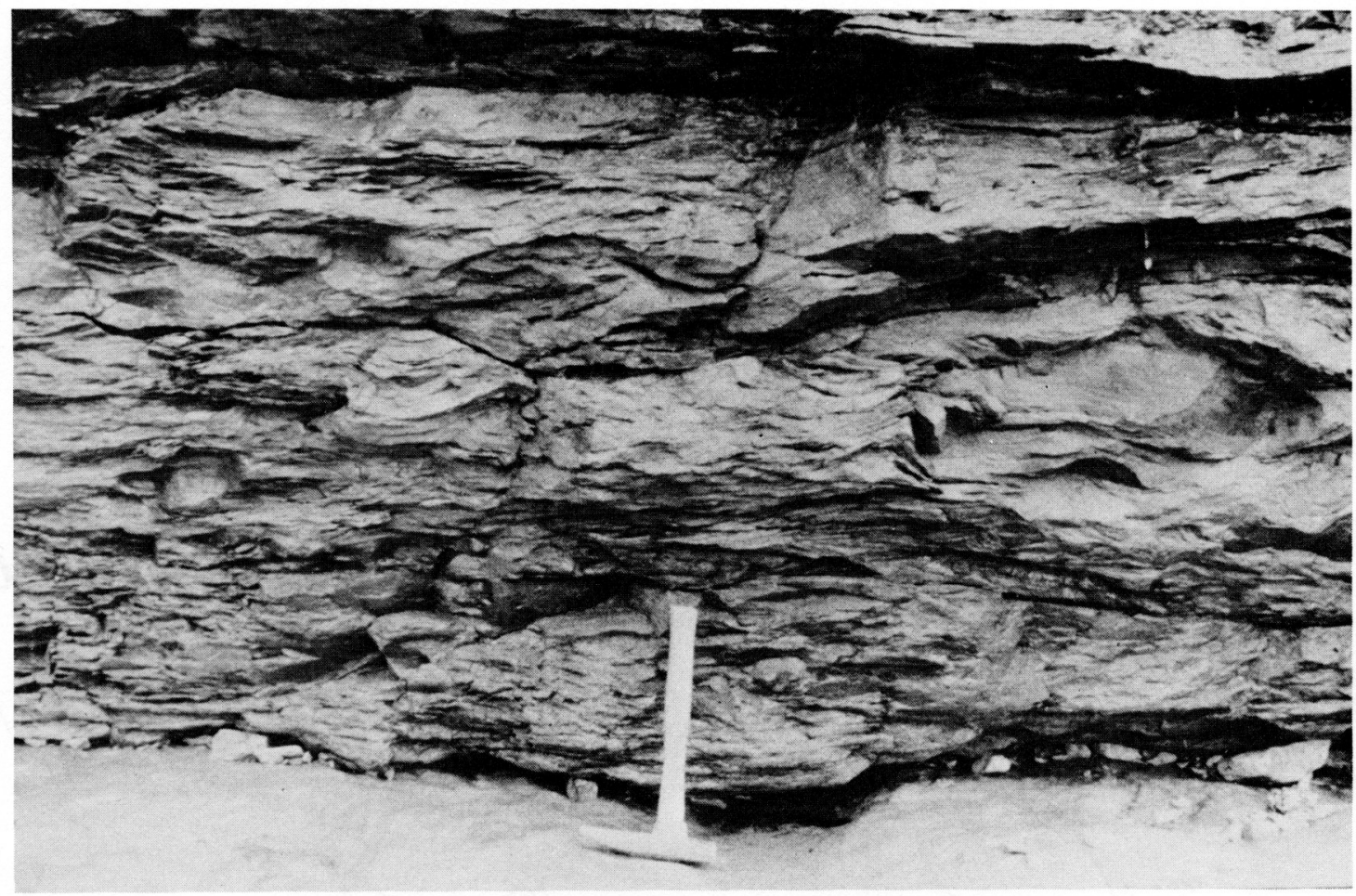

Fig. 3 - "Wavy" bedded sandstone, reflecting oversteepened crossbedding, just southeast of Point Aconi, Sydney Coalfield. Hammer is 33 $\mathrm{cm}$ long.

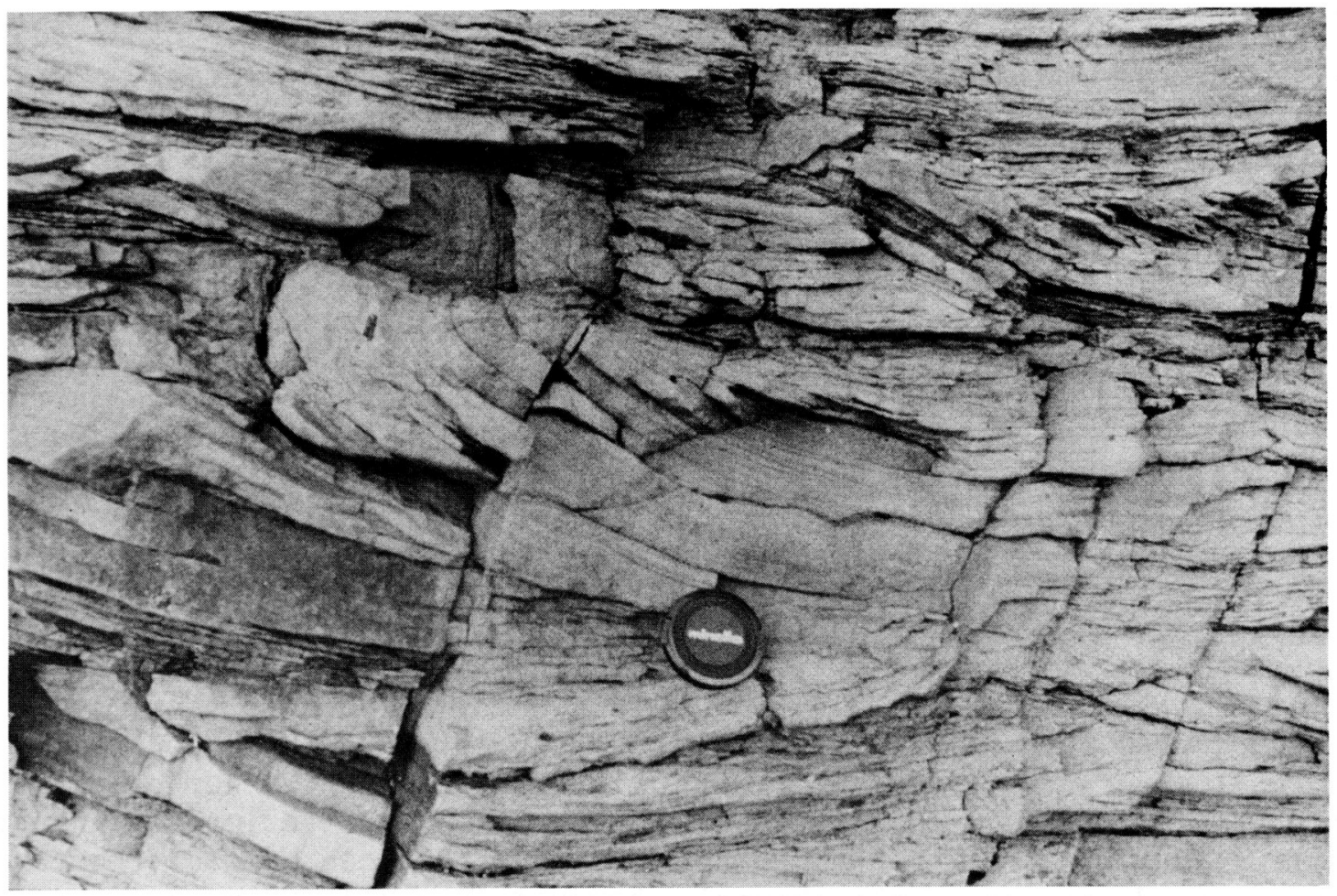

Fig. 4 - Detail of oversteepened crossbedding, just south of Cranberry Point, Sydney Coalfield. Lens cap is $55 \mathrm{~mm}$ across. 
tion structures (e.g. crossbedding, rib and furrow, ripple drift and parting lineation), are excellently preserved.

During the course of the present study, 167 crossbeds, 88 ripple foreset-laminations and 34 parting lineations were measured, many others being rejected because soft-sediment deformation had so altered their directional properties that no unequivocal measurements could be made. Orientation data from these structures are presented in Figures 5 , 6 and 7 , clearly showing that the main direction of sediment transport was to the northeast, rather than to the southeast as was previously thought.
Subsidiary sediment transport trends to the northwest and southeast, approximately perpendicular to the main northeasterly transport direction, have been noted in ripple foreset laminations and parting lineation (Figs. 6 and 7 ). The measurements were obtained from sandbodies interpreted here as levee and crevasse-splay deposits.

\section{SIGNIFICANCE}

The balance of evidence to date, from surface and subsurface information, indicates a coal-measures source area to the southwest of the Sydney Coalfield, not in the Cape Breton Highlands as suggested by most previous workers.

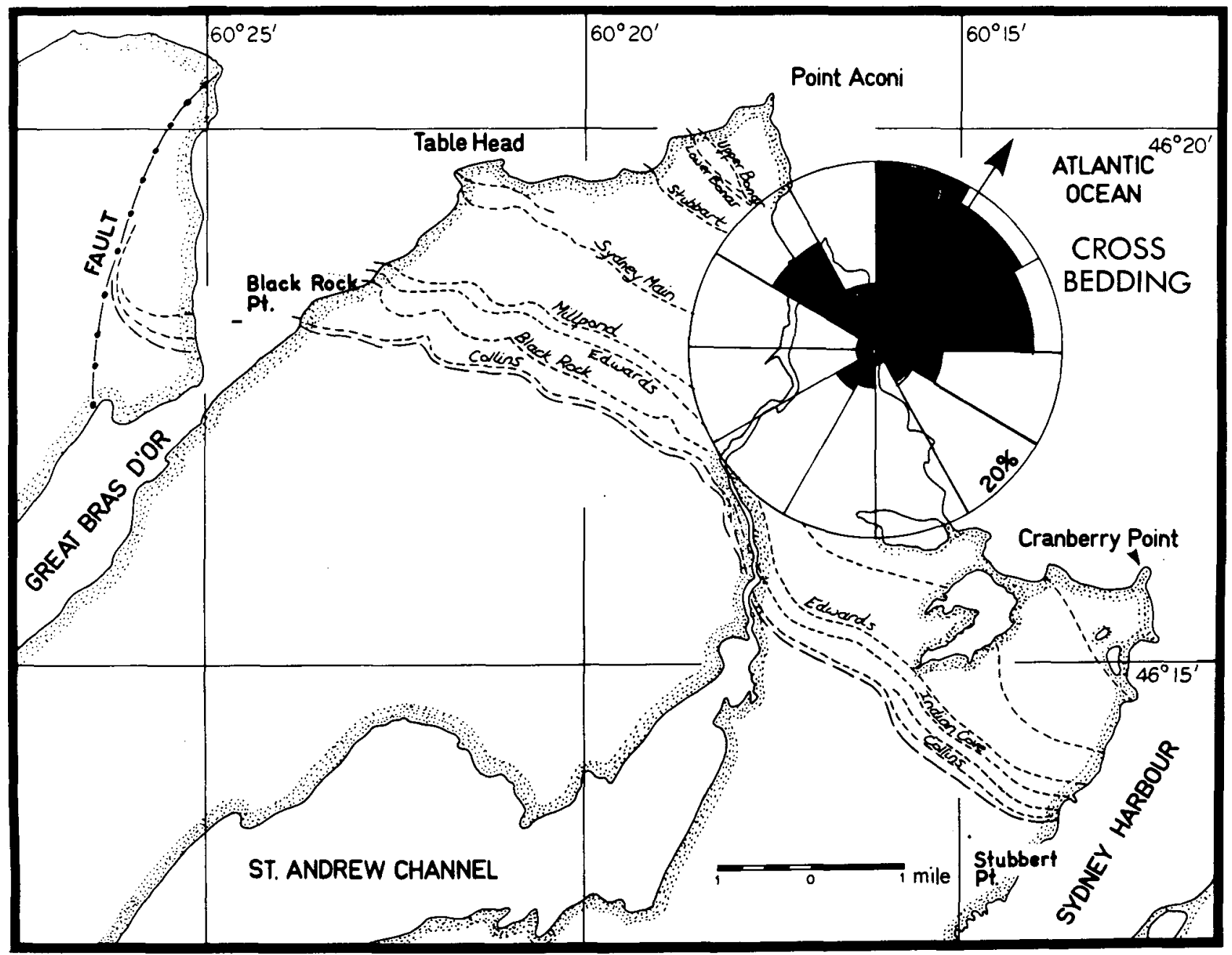

Fig. 5 - Rose diagram of 167 crossbeds in the Point Aconi area, Sydney Coalfield. Vector direction of sediment transport is $32 \%$, vector strength $46 \%$. Names (i.e. Upper Bonar, Lower Bonar, Stubbart, etc.) are those of the major coal seams. 
Orientation data obtained from primary directional structures in surface exposures show a close correlation with the channel directions mapped in underground workings. Knowledge of paleocurrent directions and channel distributions are of extreme importance in the prediction of unstable roof conditions, occurrence of "washouts" etc., particularly in undersea mining where boreholes are lacking. In the same context, the mapping of channels and sediment dispersal patterns ensures that the possibility of such geological hazards is taken into account when reserve estimates are made, and provides information necessary in the selection of new development areas.

Paleogeographic reconstruction suggest the possibility of extensive coalbearing sequences being present in the Westphalian succession in the offshore part of the Sydney Basin between Cape Breton Island and Newfoundland. If this is so, there is a real possibility that marine intercalations are present within the coal measures lying further offshore to the northeast and east from the present mining area. Such close proximity

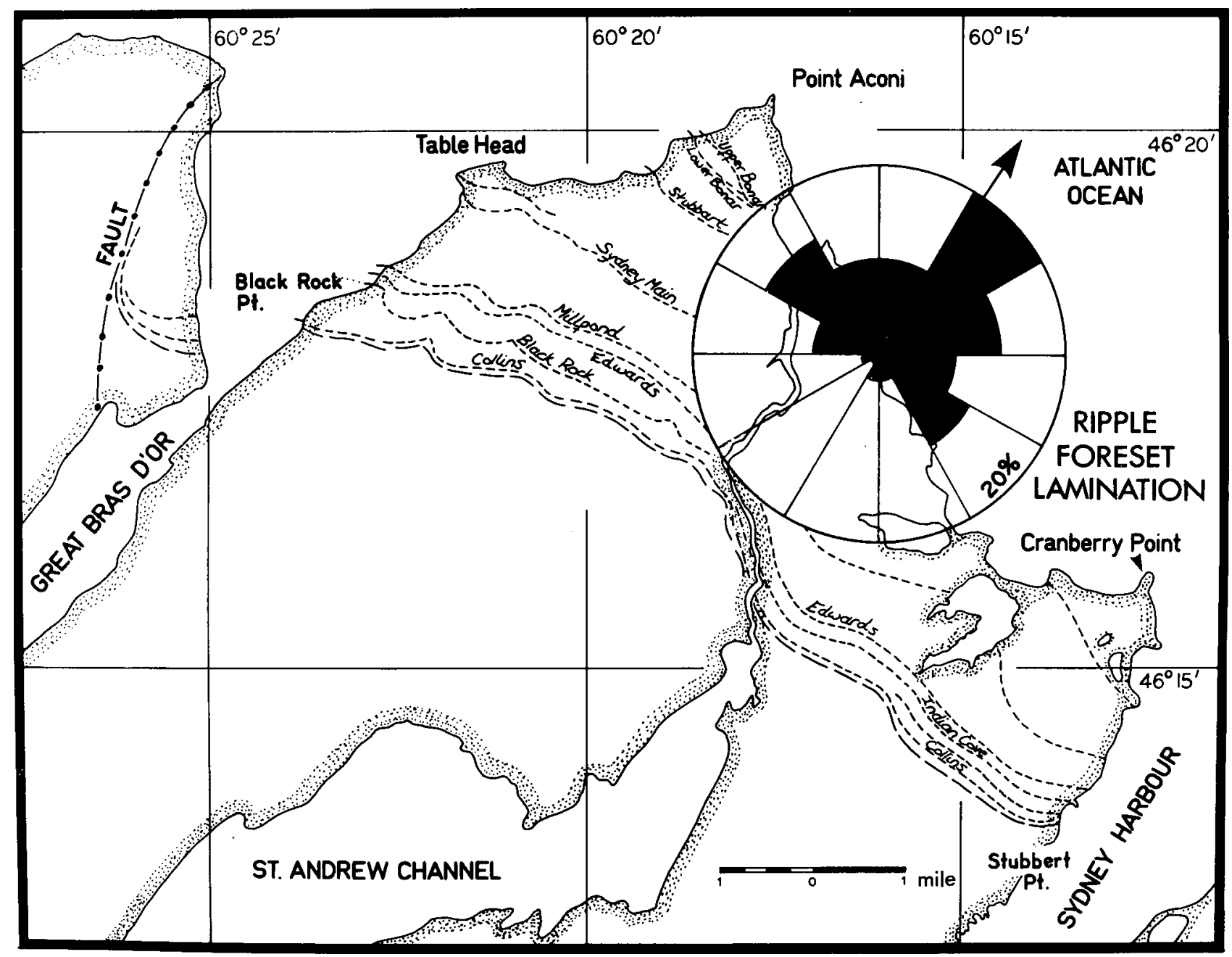

Fig. 6 - Rose diagram of 88 ripple-foreset laminations in the Point Aconi area, Sydney Coalfield. Vector direction of sediment transport is $35^{\circ}$, vector strength 39 . Note the subsidiary northwesterly and southeasterly orientations of ripple-foreset laminations (probably crevasse-splay deposition), approximtely perpendicular to the prevailing northeasterly direction of sediment transport. 


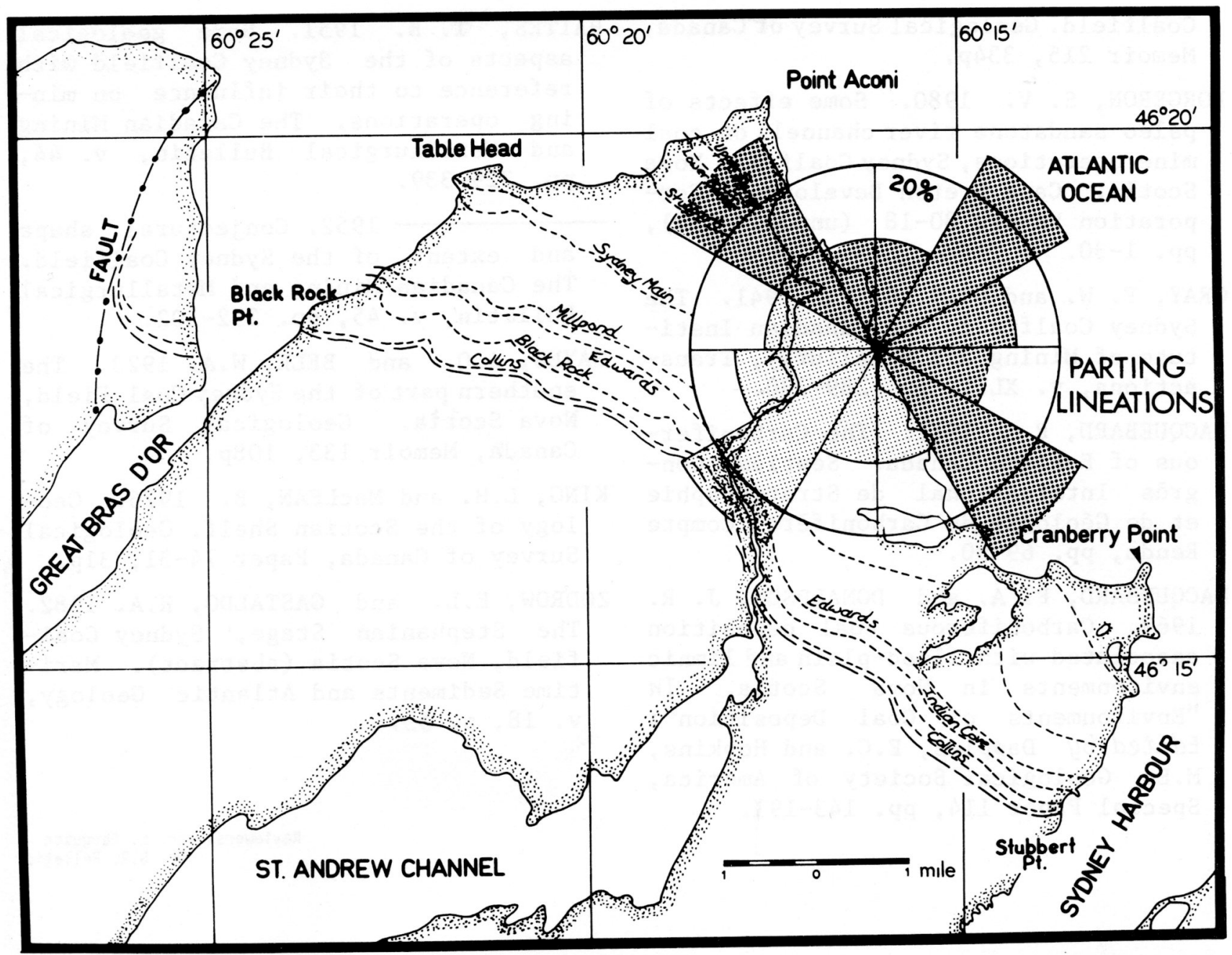

Fig. 7 -Rose diagram of 34 parting lineations in the Point Aconi area, Sydney Coalfield. Note the "two-way" bimodal orientations of the parting lineations of which one is parallel to the subsidiary northwesterly and southeasterly directions of possible crevasse-splay deposition (cf. Figures 4 and 5).

to marine strata would support Hacquebard and Donaldson's (1969) contention that the Sydney Coalfield represents a paralic environment of deposition, providing a better basis for correlation with the Westphalian of Europe; and would aid in the pre-rift trans-Atlantic paleogeographic reconstruction of the Euro-American part of Pangaea.

\section{ACKNOWLEDGEMENTS}

Acknowledgements to the Geological Survey of Canada are made for logistical assistance in the field (P.D.) and to the Geological Society of London for financial assistance (P.D.). Financial assistance from N.S.E.R.C. is gratefully acknowledged (v.d.P.). Permission by the Cape Breton Development Corporation to publish some of their data is much appreciated. Mrs. S. Townsend and $\mathrm{Mr}$. R. McCulloch of the Geology Department, University of New Brunswick typed the manuscript and completed the photographic work respectively. Drafting was done by Mrs. S. Aitken. We wish to thank Drs. L. Ferguson, B.R. Pelletier, P.A. Hacquebard and D.J.C. Laming for their constructive criticism of the original manuscript.

BELL, W.A. 1938. Fossil flora of Sydney 
Coalfield. Geological Survey of Canada, Memoir 215, 334p.

FORGERON, S. V. 1980. Some effects of paleo sandstone river channels on coal mine operations, Sydney Coalfield Nova Scotia. Cape Breton Development Corporation Report 80-18 (unpublished), pp. 1-30.

GRAY, F. W. and GRAY, R. H. 1941. The Sydney Coalfield. The Canadian Institute of Mining and Metallurgy, Transactions, v. XLIV, pp. 289-330.

HACQUEBARD, P.A. 1972. The Carboniferous of Eastern Canada. Septième Congrès International de Stratigraphie et de Géologie du Carbonifère, Compte Rendu, pp. 69-90.

HACQUEBARD, P. A. and DONALDSON, J. R. 1969. Carboniferous coal deposition associated with flood-plain and limnic environments in Nova Scotia. In "Environments of Coal Deposition": Edited by Dapples, E.C. and Hopkins, M.E. Geological Society of America, Special Paper 114, pp. 143-191.
HAITES, T. B. 1951. Some geological aspects of the Sydney Coalfield with reference to their influence on mining operations. The Canadian Mining and Metallurgical Bulletin, v. 44, pp. 329-339.

1952. Conjectural shape and extent of the Sydney Coalfield. The Canadian Mining and Metallurgical Bulletin, v. 45, pp. 292-302.

HAYES, A.O. and BELL, W.A. 1923. The southern part of the Sydney Coal Field, Nova Scotia. Geological Survey of Canada, Memoir 133, 108p.

KING, L.H. and MacLEAN, B. 1976. Geology of the Scotian Shelf. Geological Survey of Canada, Paper 74-31, 31p.

ZODROW, E.L. and GASTALDO, R.A. 1982. The Stephanian Stage, Sydney Coalfield, Nova Scotia (abstract). Maritime Sediments and Atlantic Geology, v. 18, p. 55 . 